\title{
Studi Awal Kontrol Pergerakan Meja Radiologi
}

\author{
Basuki Rahmat, Doddy Karyanto, Sugeng Santoso \\ Program Studi Teknik Elektromedik, Fakultas Teknik \\ Universitas Widya Husada Semarang \\ Jl. Dr. Soetomo No.16, Randusari, Kota Semarang, Jawa Tengah Telp. (024) 70773434 Kode pos 50244 \\ e-mail: basuki.weha@gmail.com
}

\begin{abstract}
Abstrak - Instalasi radiologi di rumah sakit memiliki banyak sekali instrumentasi yang digunakan untuk pengambilan citra anatomi tubuh pasien, salah satu instrumentasi yang ada adalah meja pasien pesawat radiologi. Meja pasien radiologi tidak sama seperti meja pada umumnya tetapi memiliki fungsi tertentu dimana meja radiologi dapat digerakan secara sliding, tilting, treunderelnberg. Meja radiologi merupakan bagian dari system alat radiologi secara keseluruhan. Tujuan dari penelitian ini adalah merancang sistem kontrol alat simulasi meja radiologi tipe fluoroscopy yang dapat digerakan secara sliding, tilting, dan treundelenberg yang diharapkan dapat dijadikan model pembelajaran bagi mahasiswa teknik elektromedik. Metode yang yang digunakan pada penelitian ini adalah dengan membuat rancang bangun sistem kontrol alat simulasi pergerakan meja pasien radiologi fluoroscopy yang dapat digerakan secara sliding, tilting, dan treundelenberg.
\end{abstract}

Kata Kunci : Pesawat Radiologi, Tilting, Sliding, Treundelenberg.

\begin{abstract}
Radiology installations in hospitals have a lot of instrumentation that is used for taking anatomical images of the patient's body, one of the existing instrumentations is the radiology plane patient table. The radiology patient table is not the same as a table in general but has a specific function where the radiology table can be moved by sliding, tilting, treunderelnberg. The radiology table is part of the overall radiology equipment system. The purpose of this research is to design a control system for a radiology table simulation device type fluoroscopy that can be moved by sliding, tilting, and treundelenberg which is expected to be used as a learning model for students of electrical engineering. The method used in this study is to design a control system for simulating fluoroscopy radiology patient table movement that can be moved by sliding, tilting, and treundelenberg.
\end{abstract}

Keywords : Radiological, Tilting, Sliding, Treundelenberg.

\section{PENDAHULUAN}

Program Studi DIII Teknik Elektro Medik merupakan pendidikan vokasi yang mempelajari teknik operasional, perawatan, perbaikan, dan kalibrasi peralatan kesehatan. Salah satu peralatan kesehatan yang dipelajari di Program Studi DIII Teknik Elektro Medik adalah pesawat radiologi. Dimana pada proses pembelajaran ini akan diajarkan bagaimana proses atau cara timbulnya Sinar-X, cara mengoperasionalkan, cara merawat, cara memperbaiki dan cara mengkalibrasi pesawat radiologi.

Proses pembelajaran vokasi untuk ranah D III diharapkan luarannya sanggup bekerja secara terampil. Keterampilan yang didapat tidak hanya diperoleh pada proses pembelajaran secara teoritis saja tetapi lebih banyak diperoleh dari proses pembelajaran praktek.

Pada artikel ini akan dibahas tentang system control pergerakan meja radiolgi, dimana ada beberapa pergerakan meja secara tilting, pergerakan meja secara sliding, pergerakan meja secara treundelenberg, dan hasil dari pengujian system control yang sudah dilakukan pada proses penelitian ini.

\section{TINJAUAN PUSTAKA}

\subsection{Prinsip Kerja Meja Radiologi}

Pada dasarnya semua pemeriksaan untuk mendiagnosa penyakit dapat dilakukan dengan menggunakan fluoroscopy, baik menggunakan bahan kontras ataupun tidak menggunakan bahan kontras. Pada proses pemotretan atau diagnosa dengan sistem fluoroscopy maka diperlukan bahan kontras. Pemeriksaan menggunakan kontras guna melihat letak kontras dan objek yang ingin di diagnosa.

Meja pasien fluoroscopy pada proses pemeriksaaan akan bergerak mengikuti objek yang akan diperiksa atau objek yang akan didiagnosa. Pergerakan meja pasien ini diposisikan hingga letak objek yang akan dicari dapat terlihat dengan tepat. Pada proses pergerakan mencari objek yang akan didiagnosa maka sudut kemiringan meja yang didapat pun tidak dapat dicapai dengan nilai mutlak, sehingga sudut yang diperoleh dalam pemeriksaan pun tidak dapat direncanakan sebelumnya oleh fotografer. Kecuali dengan pemeriksaan khusus seperti pemeriksaan lutut dengan kasus Osteoartritis yang posisi meja 
pasiennya harus diposisikan dalam sudut $90^{\circ}$ atau tilting.

Ada tiga sistem pergerakan meja fluoroscopy di instalasi radiologi yang digunakan dalam pemeriksaan pasien, pergerakan meja fluoroscopy yang dimaksud yaitu:

a. Gerak meja Tilting, pergerakan meja tilting adalah pergerakan di mana meja radiology berputar $90^{\circ}$ searah jarum jam.

b. Gerak meja Treundelenberg adalah pergerakan meja pasien dengan perputaran sebesar $18^{\circ}-$ $20^{\circ}$ dimana arah putarannya berlawanan dengan arah jarum jam.

c. Gerak sliding adalah pergerakan meja pasien bergeser kea rah kepala dan kaki atau biasa disebut pergerakan maju dan pergerakan mundur, serta pergerakan ke kanan dan ke kiri.

\subsection{AVR Atmega 8535}

Sistem kontrol yang digunakan pada penelitian studi awal kontrol pergerakan meja radiologi ini menggunakan mikrokontroler Atmega 8535. Dimana mikrokontroler merupakan operasi secara keseluruhan pada sistem komputer yang dikemas menjadi sebuah chip di mana di dalamnya terdapat mikroprosesor, kanal masukan dan keluaran (I/O), memori serta pengubah sinyal analog ke dalam bentuk sinyal digital atau Analog to Digital Converter.

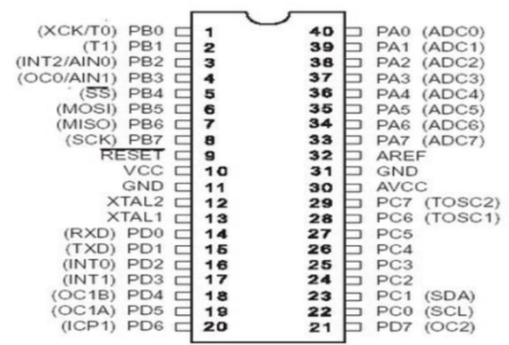

Gambar 1. Port Mikrokontroller Atmega 8535

Secara umum konfigurasi dan fungsi pin ATMega8535 dapat dijelaskan sebagai berikut.

a. VCC Input sumber tegangan $(+)$

b. GND Ground (-)

c. Port A (PA7 ... PA0) Berfungsi sebagai input analog dari ADC (Analog to Digital Converter). Port ini juga berfungsi sebagai port $\mathrm{I} / \mathrm{O}$ dua arah, jika ADC tidak digunakan.

d. Port B (PB7 ... PB0) Berfungsi sebagai port I/O dua arah. Port PB5, PB6 dan PB7 juga berfungsi sebagai MOSI, MISO dan SCK yang dipergunakan pada proses down loading.

e. Port C (PC7 ... PC0) Berfungsi sebagai port $\mathrm{I} / \mathrm{O}$ dua arah.

f. Port D (PD7 ... PD0) Berfungsi sebagai port I/O dua arah. Port PD0 dan PD1 juga berfungsi sebagai RXD dan TXD, yang dipergunakan untuk komunikasi serial.

g. RESET Input reset.

h. XTAL1 Input ke amplifier inverting osilator dan input ke sirkuit clock internal.

i. XTAL2 Output dari amplifier inverting osilator.

j. AVCC Input tegangan untuk Port A dan ADC.

k. AREF Tegangan referensi untuk ADC.

\subsection{IC L293D}

Proses kendali perputaran motor pada meja radiologi dikendalikan oleh driver motor di mana komponen yang digunakan adalah IC L293D. Proses pengontrolan dilakukan pada kanal PLC Zelio, SR2, B201 BD dimana kecepatan putaran dapat diatur menggunakan perubahan lebar pulsa atau Pulse Width Modulator. Pada IC L293D terdapat dua rangkaian H-Bridge. Tegangan masukan yang dibutuhkan oleh sistem kontrol motor ini sebesar $12 \mathrm{Vdc}$, spesifikasi pada sistem memungkinakan untuk diatur sampai tegangan maksimal sebesar 36 Vdc. Sementara arus maksimal yang mampu dilewatkan sebesar 1 Ampere. Selisih amplitude tegangan logic yang dihasilkan sebesar 1,5 Volt. Konfigurasi kanal pada IC L293D dapat dilihat pada Gambar 2.

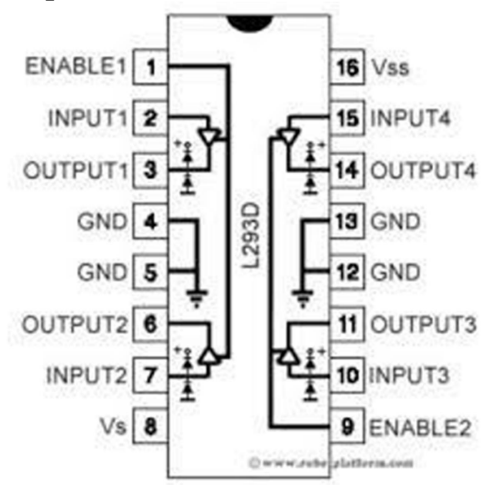

Gambar 2. Konfigurasi Kanal IC L293D

\section{METODE}

Ada beberapa tahapan yang dilakukan dalam merealisasikan sistem kontrol pergerakan meja radiologi yaitu perancangan di komputer, perancangan purwarupa, pembuatan purwarupa, dan pengujian purwarupa. Penelitian yang penulis lakukan memiliki target luaran berupa model simulasi meja radiologi yang dapat bekerja sesuai dengan kondisi alat sesungguhnya dimana dapat bergerak secara tilting, sliding, dan treundelenberg.

\subsection{Perencanaan Blok Diagram}

Proses yang pertama kali dilakukan adalah merancang system yang dibutuhkan dalam proses kontrol sistem yang akan digunakan. Rancangan 
sistem tadi digambarkan dalam sebuah blok diagram, dimana akan digambarkan blok-blok sistem yang akan dibutuhkan, blok sistem yang dibutuhkan dapat dilihat seperti pada gambar 3 .

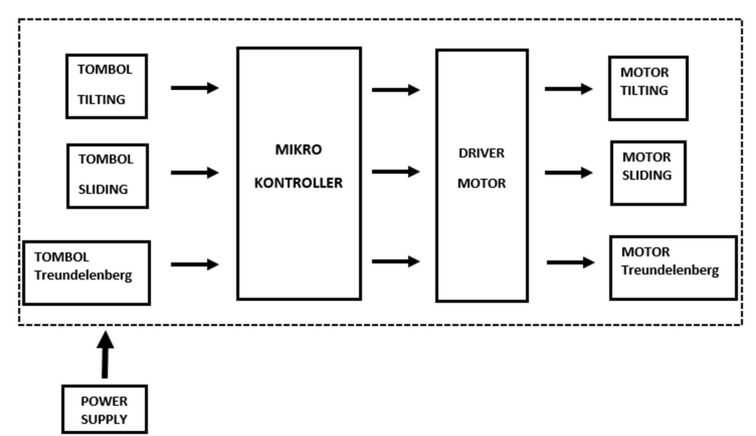

Gambar 3. Blok Diagram Kontrol Meja Radiologi

Setelah blok diagram dirancang sesuai dengan kebutuhan, selanjutnya dibuat alaur cara kerja per masing masing blok, fungsinya adalah untuk mendapat gambarann apakah system yang dirancang akan bekerja dengan baik atau tidak, jika dirasa ada sistem yang belum sempurna atau terlewat maka dapat terlihat pada proses perancangan blok diagram sehingga dapat dimungkinkan untuk menambah blok system lagi. Secara garis besar, proses kerja yang akan dirancang sesuai dengan blok diagram pada gambar 1 adalah sebagai berikut, ketika blok rangkaian power supply diberi sumber tegangan 220 Vac dan alat dihidupkan, maka output tegangan power supply menghasilkan tegangan $12 \mathrm{Vdc}$ yang akan di supply untuk mikrokontroler dan tegangan 12 Vdc yang akan di supply untuk ketiga motor tersebut.

\subsection{Sistem Kontrol Motor}

Pada sistem kontrol pergerakan meja radiologi digunakan sistem control Atmega 8535 dengan driver motor yang terintegrasi sehingga dapat untuk mengontrol pergerakan tiga buah motor sekaligus. Pergerakan tilting dan treundelenberg digerakan oleh motor 1, pergerakan sliding maju dan sliding mundur digerakan oleh motor 2, pergerakan sliding kanan dan sliding kiri digerakan oleh motor 3 .
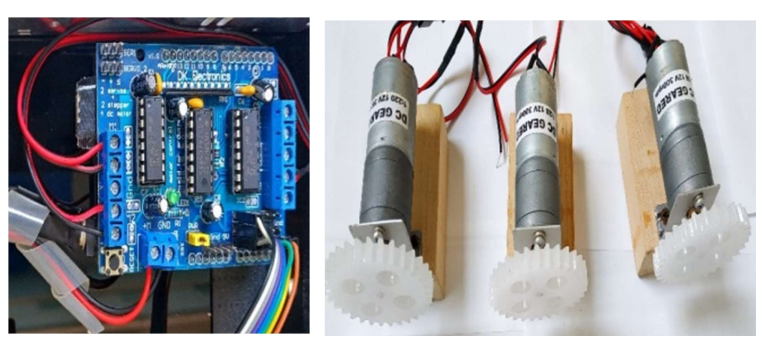

Gambar 4. Sistem Kontrol Motor

\section{HASIL DAN PEMBAHASAN}

Dari hasil uji coba purwarupa secara keseluruhan dimana sistem sudah terpasang semua didapat pergerakan motor 1 untuk gerak treundelenberg dapat bekerja dengan baik dimana arah putaran ke kiri atau berkebalikan arah jarum jam. Hasil uji coba pada pergerakan motor 1 untuk gerak tilting dapat bekerja dengan baik dimana motor berputar kearah kanan atau berputar sesuai arah jarum jam. Hasil uji coba pada pergerakann motor 2 untuk gerak sliding maju didapat pergerakan motor 2 berputar ke kanan atau putaran sesuai arah jarum jam, pada gerak sliding mundur didapat pergerakan motor 2 berputar ke kiri atau putaran berkebalikan arah jarum jam. Hasil uji coba pada pergerakann motor 3 untuk gerak sliding kanan didapat pergerakan motor 3 berputar ke kanan atau putaran sesuai arah jarum jam, pada gerak sliding kiri didapat pergerakan motor 3 berputar ke kiri atau putaran berkebalikan arah jarum jam.

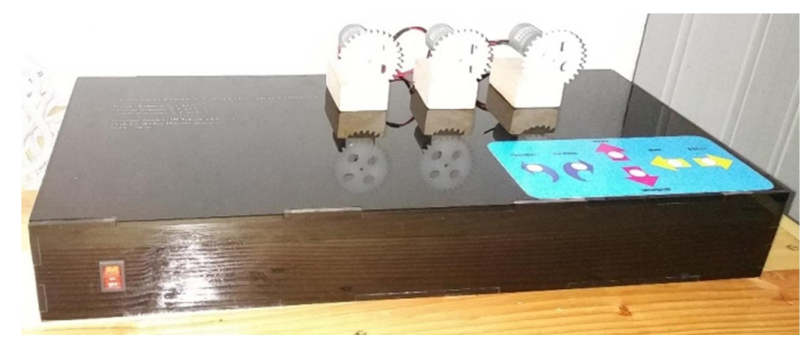

Gambar 5. Purwarupa Sistem Kontrol Pergerakan Meja Radiologi

Tabel 1. Data Hasil Pengujian

\begin{tabular}{ccc}
\hline Gerak & Arah Putaran & Kecepatan \\
\hline Sliding & Kanan dan Kiri & 20 RPM \\
Tilting & Kanan dan Kiri & 15 RPM \\
Treundelenberg & Kanan dan Kiri & 10 RPM \\
\hline
\end{tabular}

\section{KESIMPULAN}

Setelah melakukan perancangan, pengujian dan implementasi dalam system secara keseluruhan sehingga didapat hasil penelitian, maka dari hasil penelitian yang telah dilakukan dapat diambil kesimpulan sebagai berikut; Pergerakan motor 1 untuk simulasi gerak treundelenberg meja radiologi dapat bekerja dengan baik. Pergerakan motor 2 untuk simulasi gerak tilting meja radiologi dapat bekerja dengan baik. Pergerakan motor 3 untuk simulasi gerak sliding maju dan sliding mundur pada meja radiologi dapat bekerja dengan baik. Pada penelitian berikutnya dapat diteruskan dengan membuat system mekanik untuk meja radiologi sehingga system yang terbentuk dapat bekerja secara utuh. 


\section{DAFTAR PUSTAKA}

[1] Prima WW, Basuki R, Agung S N, Rancang Bangun Alat Penghitung Indeks Massa Tubuh Otomatis. Prosiding Seminar Nasional Energi Telekamunikasi dan Otomasi (SNETO) 2017. ISBN : 978-602-74127-4-3. http://ebook.itenas.ac.id/index.php?p=fstream\&fi $\underline{\mathrm{d}=28 \& \mathrm{bid}=22}$

[2] Y. M .Dinata, Arduino Itu Mudah, Jakarta: PT Elex Media Komputindo, 2005

[3] Abdul Kadir. 2012. Panduan Praktis Mempelajari Aplikasi Pemrograman Menggunakan Arduino.Yogyakarta:Andi Offset
[4] Lingga Wardhana, Belajar Sendiri Mikrokontroler AVR seri ATMega 8535: Simulasi, Hardware, dan Aplikasi. Yogyakarta: Andi Publisher, 2006

[5] Purnomo, R. D. (2013, Oktober 25). Pemeriksaan Radiologi dengan Media Kontras.

[6] Jazi Eko Istiyanto, Pengantar Elektronika dan Instrumentasi (Pendekatan Projek Arduino dan Android), Andi Yogyakarta, 2013. 